\title{
A gyermekkori invaginatio modern értelmezése és kezelése
}

\author{
Bodnár Dóra dr. - Kiss Ákos Levente dr. - Réti Gyula dr. \\ Borsod-Abaúj-Zemplén Megyei Központi Kórház és Egyetemi Oktatókórház, \\ Gyermeksebészeti, Traumatológiai és Égési Osztály, Miskolc
}

\begin{abstract}
Az invaginatio az egyik leggyakoribb gyermekkori akut hasi kórkép, melynek értelmezése, kezelése lényegesen változott az elmúlt évtizedekben. Patogenezisében korábban a hypertrophiás Peyer-plakkok és polipok tehetetlenségének tulajdonítottak elsődleges szerepet. A lipopoliszacharid indukálta invaginatio állatmodelljének megjelenésével, a rotavírus-vakcina bevezetésével, a szezonalitással és az enteralis idegrendszer postnatalis változásaival nyert újabb ismeretek nyilvánvalóvá tették, hogy a bélmotilitasnak is szerepe van az etiológiában. A kezelésben alapvetően a konzervatív eljárások váltak dominánssá, melyek hatékonysága egyre növekedett. A korábban röntgen-képerôsítő alatt végzett hidrosztatikus desinvaginatiót kiváltotta a biztonságosabbnak és hatékonyabbnak tartott pneumatikus desinvaginatio, majd a sugárterhelés kiváltása céljából az ultrahangkontroll alatt végzett hidrosztatikus módszerhez tértek vissza. A kórházi felvétel helyett egyre több intézetben az ambuláns ellátást preferálják. Vitatott a desinvaginatiós manôver alatt alkalmazott gyógyszerek - például a glükagon és a ciklooxigenázgátlók - szerepe a hatékonyság növelésében és a recidíva kivédésében. A mútéti kezelésben a nyílt mútét helyett a minimálinvazív laparoszkópos eljárás tör előre. A szerzők az irodalmi adatok áttekintésével elemzik az invaginatio értelmezésében és kezelésében történt változásokat és az aktuális trendet.
\end{abstract}

Orv Hetil. 2020; 161(32): 1331-1338.

Kulcsszavak: invaginatio, bélelzáródás, gyermek/gyermekkor

\section{Modern understanding of intussusception and recent trends in management}

Intussusception is one of the most common abdominal emergencies in children. The understanding of its aetiology and management has changed significantly over the last decades. Earlier, the hypertrophic Peyer's patches and polyps were considered responsible, but with the knowledge obtained from the lipopolysaccharide-induced animal model of intussusception, the rotavirus vaccination, the seasonality and the postnatal changes of the enteric nervous system it became clear that the intestinal motility plays a key role in the aetiology. The efficacy of non-operative management is continuously improving. The radiologists initially moved from the hydrostatic X-ray-controlled reduction towards the air enema (pneumatic reduction), however, nowadays, there is a shift back to hydrostatic procedures but under ultrasound guidance to reduce radiation exposure. In many institutions, intussusception is managed as day-case rather than as an inpatient case. The role of medications like glucagon and cyclo-oxygenase inhibitors used during reduction manoeuvres and prevention of recurrence is still controversial. Surgical management is shifting towards laparoscopy. The authors herein reviewed the current literature to present recent insights into understanding the pathogenesis and management updates.

Keywords: intussusception, intestinal obstruction, children/childhood

Bodnár D, Kiss ÁL, Réti Gy. [Modern understanding of intussusception and recent trends in management]. Orv Hetil. 2020; 161(32): 1331-1338.

(Beérkezett: 2020. március 4.; elfogadva: 2020. április 20.)

\author{
Rövidítések \\ iv. = intravénás; L-NAME = L-nitro-arginin-metil-észter; LPS \\ = lipopoliszacharid; $\mathrm{NO}=$ nitrogén-monoxid; $\mathrm{NOS}=$ nitro- \\ gén-oxid-szintetáz; NSAID = (non-steroidal antiinflammatory \\ drug) nemszteroid gyulladáscsökkentő gyógyszer
}

\section{Történeti áttekintés}

Az invaginatio, vagy intussusceptio során általában a vékonybél egy szakasza - a leggyakrabban a terminalis ileum - teleszkópszerüen betüremkedik a tőle distalisabban 
elhelyezkedő bélszakaszba. A betegség első leírása a XVII. századra vezethető vissza, és Barbette nevéhez füződik. Hutchinson végzett elsőként sikeres mútétet gyermeken a végbélen át kitüremkedő invaginatum sikertelen repozícióját követően [1], majd Hirschsprung számolt be először hidrosztatikus desinvaginatióval szerzett tapasztalatokról több beteg megfigyelése alapján $[2]$.

\section{Gyakoriság}

$\mathrm{Az}$ invaginatio a leggyakoribb gyermekkori, bélobstrukciót okozó akut hasi kórkép; a leginkább 5-9 hónapos kor körül fordul elő, 3 éves kor felett már ritka. Fiúkban háromszor gyakoribb, de négyéves kor felett ez az arány már 8 : 1. Újszülöttkorban nagyon ritka, az esetek 75\%-a az első két életévben fordul elő [3].

Fejlett nyugati országokban 30-70 eset jut 100000 csecsemőre, míg ázsiai országokban - például Japánban vagy Vietnamban - lényegesen gyakoribb (185-302/ 100000 csecsemő). A mortalitás a fejlett országokban $1 \%$ alatt van, míg fejlődő országokban a $9 \%$-ot is elérheti [4].

\section{Kóreredet}

A tradicionális elképzelés szerint az orális bélszakaszt a perisztaltika sodorja az attól distalisan lévő bélbe. Az invaginatio kialakulásában nagy szerepe lehet az ún. „vezetô- vagy vezérpontnak", amelyet mint tehetetlen tömeget a perisztaltika sodor tovább. Vezetőpont lehet hypertrophiás Peyer-plakk, appendix vermiformis, Meckel-diverticulum, ectopiás pancreas a bélfalban, polip, bélanasztomózis varratvonala, buktatott appendixcsonk, idegen test, a mesenteriumon lévő, de a bél lumenébe bedomborodó, megnagyobbodott nyirokcsomó, poszttranszplantációs lymphoproliferativ elváltozások, tumorok, Burkitt-lymphoma, bélduplikáció, haemangioma, de társulhat Schönlein-Henoch-szindrómához, coeliakiához, cystás fibrosishoz és Crohn-betegséghez is. Ilyen vezérpontot általában 3 éves kor után előforduló invaginatiós esetekben látunk. A típusos életkorban a legtöbbször igazi vezérpont nincs jelen. Ebben az életkorban az invaginatio valószínúleg más okokra vezethető vissza. A kórkép gyakran gastroenteritishez vagy felső légúti huruthoz társul. Erre utalhat a szezonalitás és a vakcinákhoz kapcsolódó esetek halmozódása [2].

\section{A patogenezissel kapcsolatos további ismeretek}

Szezonalitás: Az intussusceptio gyakorisága szezonális eltérést mutat, ami általában összefügg vírusfertőzésekkel (légúti, gastrointestinalis vagy mindkettő). A legtöbb eset májusban, júniusban és júliusban jelentkezik [5-7]. $\mathrm{Az}$ invaginatiót megelőző vírusos megbetegedések előfordulási gyakorisága 20\% [8-10]. Yersinia enterocolitica okozta fertőzés következtében kialakult invaginatio is ismert [11].

Rotavírus-vakcináció: 1998-ban az Amerikai Egyesült Államokban bevezetésre került a RotaShield elnevezésű, rotavírus elleni védőoltás, ez azonban az invaginatiók fokozott kockázatával társult, ezért 1999-ben visszavonták az alkalmazását. Ezt követően két új vakcina jelent meg: 2006-ban engedélyezték a RotaTeq, illetve 2008-ban a Rotarix vakcinát. Egy 25 év anyagát felölelő vizsgálatban azt állapították meg, hogy az új vakcinák csak kismértékben emelik meg az invaginatio előfordulási gyakoriságát, azaz sokkal kisebb a kockázat [12]. Az Európai Unióban, így Magyarországon is mindkét vakcina törzskönyvezett, de nem kötelező védőoltás. A Rotarix orális vakcina, az immunizáláshoz 2 dózis beadása szükséges. A RotaTeq szintén orális vakcina, ebből a teljes immunizáláshoz 3 dózisra van szükség. A teljes vakcinációt az első esetben 24 hetes korig, az utóbbi esetben legkésőbb 32 hetes korig be kell fejezni [13].

A csecsemő önköltséges oltását a szülő kérheti. A kontraindikációk között szerepel az összetevőkkel szembeni allergia, ha a gyermek már átesett invaginatión, illetve súlyos immunbetegség.

Lipopoliszacharidmodell: Egerekben megfigyelték, hogy az intraperitonealisan beadott bakteriális lipopoliszacharid (LPS) bélbetüremkedést okoz. Kísérletes modellben lokálisan az invaginatio helyén kifejezetten magas nitrogén-monoxid (NO)-szintet regisztráltak [14]. Valószínűsíthető, hogy a nitrikus neuronokból és a hízósejtekből nagy mennyiségben felszabaduló NO mint a bél relaxációjáért felelős neurotranszmitter játszik közre abban, hogy a distalis bélszakasz túlságosan ellazul, és lehetővé teszi a proximális szakasz beletüremkedését. A NO-felszabadulást a nitrikus neuronokból előidézheti infekció vagy mesterségesen adott LPS is. Egy, különböző életkorú sertéseken végzett, az enteralis idegrendszert feltérképező vizsgálat szerint a nitrikus innerváció az ileocaecalis billentyű területén a legsưrúbb, de ez a postnatalis időszakban fokozatosan csökken. Ez a megfigyelés és az LPS-modell együtt magyarázhatja, hogy az invaginatio miért ileocaecalisan alakul ki a leggyakrabban, és ez a mechanizmus miért nem gyakori a csecsemókor vége felé, kisdedkorban [15].

\section{Állatkisérletes modellek alapján az alábbi tényezôk szerepe is feltételezhetó}

Gasztrin: A fokozott perisztaltikának az invaginatióban játszott szerepét számos közlemény tárgyalja. Gasztrininjekció állatkísérletben fokozott perisztaltikát idéz elő. Jin és mtsai emelkedett gasztrinszintet mértek invaginatión átesett csecsemókben az egészséges kontrollokhoz képest [16].

Mérgezések: Acetil-kolin-észteráz-inhibitor-tartalmú rovarirtó szerek, szerves foszforsavészterek okozta mérgezések is okozhatnak invaginatiót. Kutyákban növekvő adagokban orálisan adott piridosztigmin fokozott intes- 
tinalis perisztaltikához, hasmenéshez és invaginatióhoz vezetett [17].

Az anatómiai viszonyok: Az invaginatio folyamatában szerepet játszhat az ileocaecalis átmenet térbeli anatómiája. A caecumnak nagyobb az ileumhoz viszonyított ürmérete, és a terminalis ileum a caecum oldalába úgy csatlakozik, mint egy cső egy nagyobb edénybe. A vékonybélből az invaginatiós tumor a vastagbélbe jut, de onnan már nehezebben tud visszacsúszni. Míg az ileoilealis invaginatio spontán oldódhat, addig az ileocolicus és az ileocaecalis invaginatio spontán oldódására alig lehet számítani. Szerepe lehet a caecumot rögzítő szalagoknak is. Kutyákban a caecumot rögzítő ligamentum átvágása csökkentette a refluxgátló hatékonyságot [18]. Kérdés, hogy a szalagok átvágása segítséget nyújthat-e a recidív primer invaginatio megelőzésében.

A reflexek szerepe: Az ileocaecalis junctio speciális motilitassal bír, melyet jól definiált reflexek irányítanak. A terminalis ileum tartalma nem állandóan, hanem szakaszosan ürül a vastagbélbe, csak akkor, amikor a bélszakasz „megtelik”, ezzel biztosítva a terminalis ileumban zajló felszívódási folyamatokhoz szükséges időt. Erre utal az a megfigyelés is, hogy az ileocaecalis junctio elvesztése egyébként egészséges páciensekben tartós hasmenéshez vezethet [19], továbbá hogy rövidbélszindróma esetén az ileocaecalis billentyű jelenléte jó prognosztikai faktornak számít [20, 21].

Bár az ileocaecalis átmenet területén nem található klasszikus sphincterre utaló anatómiai képlet, azaz megvastagodott izomgyürü vagy speciális idegrendszeri struktúra [22], mérhető egy, a sphincterekre jellemző nyugalmi, magas nyomású zóna, mely a szájadékot zárva tartja. Az ileum falának feszülése elindítja a terminalis ileum perisztaltikáját és az ileocaecalis szájadék ellazulását (ileocaecalis reflex). A caecumba jutó béltartalom a caecalis nyomás emelkedése révén az ileocaecalis billentyú tónusának fokozódásához vezet (caecoilealis reflex) [23]. Ezek a reflexek biztosítják, hogy az ileocaecalis junctióban a széklet áramlása egyirányú. A caecum tartalma nem jut vissza a vékonybélbe, biztosítva a salakanyagok távozását és az alacsony csíratartalmat a vékonybélben. A fent leírt reflexeknek - fóleg a vastagbélbe türemkedett invaginatum által kiváltott caecoilealis reflexnek - jelentőségük lehet az ileocaecalis invaginatio kialakulásában és fenntartásában, aminek következtében az ileocaecalis billentyű a belecsúszott invaginatumot leszorítja, akadályozva annak spontán oldódását.

\section{Patológia}

A kóros folyamat során a proximális bélszakasz betüremkedik a tőle distalisabban lévő bélbe, kialakítva az „invaginatiós tumort", melyet három bélfalhenger alkot. A belső és a középső henger alkotja az intussusceptumot, a külső henger pedig az intussuscipiens. Az intussusceptum mesenteriuma így megtörik, a külső henger komprimálja, a vénákban pangás jön létre, a bélfalban lokális ödéma alakul ki, majd elzáródnak a vénák és végül az artériák is. A keringési zavar következtében a bél lumenébe nyálka és vér ürül, létrehozva az invaginatióra jellegzetes ún. „málnazselészerü” székletet. A vérellátási zavar miatt a bélfal nekrotizálhat, perforálhat [24]. Leírtak extrém ritka esetet, amikor az elhalt bélszakasz spontán, anális kiürülése is megtörtént, és a bél folytonossága helyreállt. Az invaginatum bizonyos esetekben spontán is oldódhat, és újra kialakulhat. Ezt a formát intermittáló invaginatiónak nevezzük [2]. Létezik az invaginatiónak recidív formája is. Ebben az esetben nagy valószínúséggel van jelen vezérpont [25]. Kannabisz okozta visszatérő invaginatio tinédzsereknél előfordulhat [26].

\section{Klinikai kép}

A klasszikus tünetek - a periodikus sírás, tapintható invaginatiós tumor, málnazselészerű széklet - ritkán jelentkeznek együtt. A legfontosabb korai kórjelző a periodikus sírás és nyugtalanság $(90 \%)$. A fokozott perisztaltika heves kólikát okoz, kisebb szünetekkel. Hányás is jelentkezhet, mely kezdetben reflexes eredetü. Az invaginatiós tumor tapintása nem mindig könnyű egy síró csecsemőnél. A véres széklet általában késői tünet. Sokszor félrevezető, és enteritis gyanúját veti fel. Nagyon fontos, hogy ha a tünetek egyike a leginkább veszélyeztetett életkorban jelentkezik ( 5 hó-3 év), mindenképpen gondolni kell az invaginatióra, és ultrahangvizsgálatot kell kérnünk. Előrehaladott esetekben a hányás, haspuffadás a kialakuló ileus jeleként értékelendő.

Kimerült, letargiás csecsemőnek is lehet invaginatiója, minden egyéb tünet nélkül is. Invaginatio kialakulhat hasi mútét után is, ilyenkor gyakran tünetszegény, a diagnózis felállítása nehezebb [24].

\section{Kórisme}

Fizikális vizsgálat: A has általános vizsgálata során keresnünk kell az ún. invaginatiós tumort. Ezt általában a jobb bordaív alatt tapinthatjuk, előfordulhat azonban a bal hypochondriumban is, hiszen a caecumba invaginálódott vékonybél továbbhaladhat a vastagbélben [24]. A fizikális vizsgálat jelentősége az ultrahang elterjedésével csökkent.

Célzott vizsgálatok: Korábban a különböző röntgenvizsgálatok álltak rendelkezésünkre. A natív hasi felvétel esetén a bélgázárnyékok mértéke és formája alapján következtethetünk az invaginatióra, de inkább az esetleges perforáció és ileus tüneteit ismerhetjük fel, mely esetekben még a mai napig segítségünkre lehet. A natív hasi felvétel alapján az invaginatiót kizárni nem lehet, ezért az ultrahangvizsgálat nem helyettesíthető.

A levegővel végzett beöntés (air enema) vagy a kontrasztanyaggal végzett irrigoszkópia nemcsak segíti a diagnózis felállítását, de a terápia lehetőségét is magában hordozza [24]. Mindkét módszer telődési hiányként mutatta az invaginatumot. 
Az első választandó lépés az ultrahangvizsgálat. A vizsgálaton az invaginatiós tumor keresztmetszeti képe, az ún. kokárdajel (vagy „céltábla”, „target” jel) jól felismerhető (1. ábra). Hosszmetszeti képen „álvese”, vagy „pseudokidney” jel észlelheto" (2. ábra). Előrehaladott esetekben, amikor a perforáció veszélye felmerül, natív hasi röntgenvizsgálat javasolt a hidrosztatikus desinvaginatio megkezdése előtt, az esetleges bélperforáció kimutatása céljából, mivel perforáció esetén ez az ellátási mód ellenjavallt.

\section{Elkülönítő kórisme}

Az invaginatiót a leggyakrabban tévesen enteritisnek diagnosztizálják a híg, véres székletürítés miatt. Emiatt fertőzőosztályra utalják a beteget. A képet bonyolítja, hogy a kórkép általában hasmenés talaján alakul ki, és tulajdonképpen annak szövődményeként is felfoghatjuk.

\section{Kezelés}

A kezelés célja a betüremkedés megszüntetése, a desinvaginatio. Ennek két fó módja a konzervatív és a mútéti megoldás. Számos kutatás folyik a gyógyszeres kezelésről, de jelenleg nincs általánosan elfogadott gyógyszeres lehetőség.

A gyógyszeres kezelés lehetséges támadáspontjai: A reflexívek és az egyes neurotranszmitterek ismerete hozzájárulhat az invaginatio kezelésének javításához. Sertésben kísérletesen kiváltott ilealis distensio okozta ileocaecalis billentyú relaxációt $\beta$-receptor-blokkoló (betanekol) és szelektív nitrogén-oxid-szintetáz (NOS)blokkoló L-nitro-arginin-metil-észter (L-NAME) segítségével gátolni lehet [27].

Ez a felismerés, az LPS-modellből megismert mechanizmussal és azzal a ténnyel együtt, hogy ciklooxigenázgátlókkal (például NSAID-okkal) az LPS-modellben az invaginatio megelőzhető, a gyógyszeres kezelés (megelőzés, recidívaprevenció, a desinvaginatio megkönnyítése) lehetőségét is jelentheti.

A már kialakult invaginatio kezelésének, a desinvaginatio hatékonyságának gyógyszeres fokozása az ileocaecalis billentyú ellazításával nem új ötlet. Korábban glükagonnal történtek próbálkozások, mert a glükagon simaizom-ellazító hatással bír; ez azonban nem terjedt el a klinikai gyakorlatban, mivel prospektív, kettős vakvizsgálatok nem bizonyították a hatásosságát [28, 29].

Sertésben a coloileocaecalis excitatiós reflexválasz LNAME jelenlétében inhibícióra változott [27]. Ez felvetheti a lehetőségét, hogy NOS blokkolásával a billentyű spazmusát oldani lehetne, és a desinvaginatio konzervatív kezelését gyógyszeresen hatékonyabbá tehetnénk, de jelenleg L-NAME-tartalmú törzskönyvezett gyógyszerről nem tudunk.

$\mathrm{Az}$ invaginatio megszüntetésére tehát jelenleg a hidrosztatikus vagy pneumatikus desinvaginatio, illetve a mútéti kezelés jön szóba. A beavatkozás előtt vénabizto-

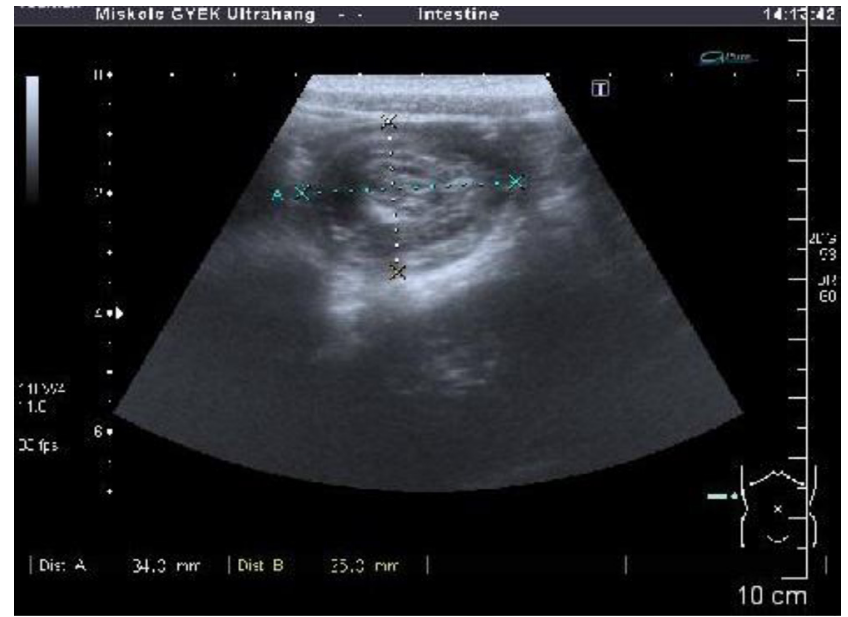

1. ábra $\quad$ Az invaginálódott bél ultrahangos keresztmetszeti képe. A koncentrikus köröket a bélfalak alkotják, a kép céltáblára hasonlít,
„target” jel

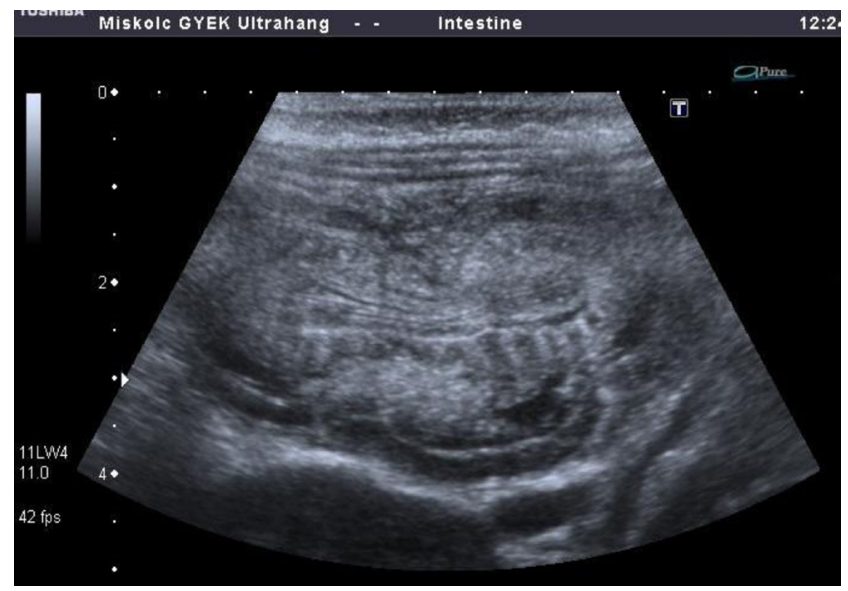

2. ábra

Az invaginatio hosszmetszeti képe ultrahangon. A kép vese keresztmetszetére hasonlít, „pseudokidney” jel

sítás szükséges, az iv. folyadékpótlást (legalább $20 \mathrm{ml} / \mathrm{kg}$ fiziológiás sóoldat bolusban) el kell kezdeni, és gondoskodni kell az életfunkciók monitorizálásáról.

Konzervatín kezelés: Az első lépésként a legtöbb esetben célszerű folyadékkal vagy gázzal (levegő) megkísérelni a desinvaginatiót. A korábban röntgenellenőrzés mellett végzett vizsgálat jelentős sugárterhelést jelentett a beteg és az ellátószemélyzet részére. Az utóbbi időben a desinvaginatiót ultrahang-ellenőrzés mellett végezzük, melynek során nincs sugárterhelés. Magyarországon a legelterjedtebb a folyadékkal (fiziológiás sóoldattal) végzett beavatkozás. Több neves intézetben levegő bejuttatásával történik a beavatkozás, abból a meggondolásból, hogy perforáció esetén a hasüregbe jutott levegő kevesebb szövődményt okoz a hasüregben, mint a folyadék.

Az esetek nagy részében a beöntésként adott levegő vagy folyadék nyomása az invaginatumot kipréseli. A hidrosztatikus desinvaginatio sikerességét jelzi, hogy a beadott folyadék vagy levegő megjelenik a vékonybélben. Amennyiben a beadott folyadék ileumba történő bejutását az ultrahang egyértelmúen nem detektálja, se- 
gítséget jelenthet a kontrasztanyagos irrigoszkópia, melynek során a vizsgálatnál alkalmazott folyadékba töltött néhány ml kontrasztanyag a vékonybélben látható. Ha az ileumba nem folyik át a folyadék, az eredményesség nem egyértelmű, ugyanis az ödémás Bauchin-billentyü is képezhet akadályt a folyadék feljutásával szemben. Ezt alátámasztja, hogy sikertelennek hitt desinvaginatio után történt mútétnél sokszor invaginatumot már nem találunk. Levegővel végzett desinvaginatio esetén a röntgenképen megjelenő appendix vermiformis azt sugallja, hogy az intussusceptiót nem lehet konzervatívan megoldani [30]. Habár a levegővel történő desinvaginatio során a levegőnyomást igyekeznek $100 \mathrm{Hgmm-en} \mathrm{tartani,}$ az appendix feltelődése azt mutathatja, hogy a nyomást már nem érdemes tovább növelni.

A legjobb módszernek számosan az ultrahang-ellenőrzés mellett folyadékkal történő desinvaginatiót tartják [31]. Bár egyelőre nincsenek bizonyítékok arra, hogy a folyadékkal vagy levegővel történő desinvaginatio valamelyike szignifikánsan eredményesebb lenne [32], nagy esetszámú összehasonlító vizsgálatok nem történtek. A desinvaginatio sikeressége megfelelő szedálással, kellően gyakorlott radiológus jelenlétével, a beöntófolyadék megfelelő nyomáskontrolljával, valamint a desinvaginatiós kísérlet megismétlésével növelhető. A konzervatív desinvaginatio az esetek több mint $80 \%$-ában sikerrel jár. Sikertelenség esetén a klinikai tapasztalatok azt mutatják, hogy ha a beteg állapota stabil, és az anamnézis nem túl hosszú, érdemes a manővert néhány óra múlva megismételni, mert akár az esetek 50\%-ában sikeres lehet [33]. A beavatkozás kétszer is elvégezhető, ha a gyermek állapota mindvégig stabil. Egy tanulmány szerint 4 esetből három alkalommal az is eredményes lehet [34]. Az ismételt desinvaginatio sikere lényegesen nagyobb, ha az elöző manőver során az invaginatum megmozdult, és a Bauchin-billentyúig visszanyomható volt .

Jól szervezett centrumokban az invaginatióknak csak kb. a 10-20\%-a kerül mütétre.

A sikeres desinvaginatio után sokan iv. antibiotikumot javasolnak a nyálkahártya feltételezett károsodása miatt [24]. Ritkán előfordul az invaginatio újbóli kialakulása, röviddel a desinvaginatiót követően. Ezt talán megelőzhetjük nemszteroid gyulladásgátlók rutinszerű alkalmazásával, ugyanis az invaginatio LPS-modelljében adott ciklooxigenázgátlók szignifikánsan csökkentették az invaginatio kialakulását, bár erre utaló klinikai tanulmányt nem találtunk.

A konzervatív kezelést a tünetek 48 óránál tartósabb fennállása, peritonealis izgalmi tünetek és masszív vérzés esetén nem célszerü megkísérelni, mert a sikertelenség valószínűsége és a perforáció veszélye nagyobb [16].

Mütéti kezelés: Sikertelen pneumatikus vagy hidrosztatikus desinvaginatio után mútét indokolt. Az operáció történhet laparotomia és laparoszkópia segítségével.

Nyílt mütét: Jobb oldali haránt laparotomiát célszerú választani. Az invaginatiós tumor kiemelése után az invaginálódott bélszakaszt kompresszió segítségével nyom- juk ki a distalis bélszakaszból. Az általános szabály szerint a belet nem szabad húzni, mert könnyen sérülhet a mesenterium és a serosa [2]. Amennyiben a bél életképtelen, vagy az invaginatum a szoros összetapadás miatt már nem tolható ki a bélből, az adott szakasz reszekciója indokolt. Amennyiben peritonitis nem áll fenn, primer anasztomózis készítése ajánlott. Súlyos peritonitis esetén, az anasztomóziselégtelenség veszélye miatt szóba jön sztóma készítése, bár erre napjainkban egyre ritkábban van szükség.

Amennyiben vezérpontot találunk, azt el kell távolítani.

$\mathrm{Az}$ appendix rutinszerü eltávolítása vitatható. Előny, hogy késóbb appendicitis nem alakulhat ki (az appendicitis esélye az egész életre vonatkoztatva kb. 6\%) [35], ugyanakkor ázsiai populációban az appendectomia után 14\%-kal több colorectalis daganatot detektáltak [36]. Ha az appendix vermiformis sérült, mi az appendectomiát elvégezzük.

Laparoszkópia: Az utóbbi években előtérbe került a laparoszkópos mütétek minél szélesebb körben történő alkalmazása. A mưtét során az invaginálódott bélrészleteket széles atraumatikus fogókkal „széthúzhatjuk”. Ez a módszer ellentmond a klasszikus „ne húzd, csak nyomd” elvnek, de kellő óvatossággal megoldható, és a relatíve nagy behatolás elkerülhetô [24, 37]. Nagy elönye, hogy ha a sikertelennek vagy kétségesnek értékelt konzervatív desinvaginatiót követően végzett mütétnél már az invaginatiónak csak a nyomait látjuk, nincs szükség nagy feltárásra. A laparoszkópos mútét az esetek zömében biztonságosnak tekinthető, még akkor is, ha az esetek egyharmadában szükséges konvertálni. Az invaginatio laparoszkópos megoldásának további előnyei, hogy a mútét és az altatás rövidebb, a beteg hamarabb táplálható és hazaengedhető [38].

\section{Szövődmények}

Radiológiai: A desinvaginatio legnagyobb szövődménye a bélperforáció [39]. Ám még így is, a különböző technikákkal végzett desinvaginatiók során extrém ritkán fordul elő, az esetek kevesebb mint 1\%-ában számolnak be róla még a báriuméra idejéból [40]. A pneumatikus és hidrosztatikus desinvaginatio elterjedésével, illetve a kevesebb mint $60 \mathrm{Hgmm}-\mathrm{en}$, lassan beadott levegő vagy folyadék alkalmazásával elkerülhető a perforáció. A bélperforáció rizikófaktorai közé tartozik a 6 hónapnál fiatalabb életkor, illetve a hosszú anamnézisidő (>36 óra) [41].

Sebészi: Az általános hasi mútétek szövődményeit sorolhatjuk ide: sebfertőzés, bélelzáródás, hasfali sérvek kialakulása.

Kiújulás és kezelése: Az esetek legfeljebb 2-20\%-ában ismétlődik az invaginatio, egyharmaduknál 24 órán belül [42]. Egyes vélemények szerint a korai recidíva (12 órán belül) lehet inkább sikertelen desinvaginatio maradványa. Egy friss kínai tanulmány szerint 2561 csecsemókori invaginatióból 2350 (91\%) esetben sikeres konzervatív 
ultrahang alatt végzett desinvaginatio után 240 (10,2\%) betegnél alakul ki recidíva 48 órán túl. 130 gyermeknél kétszer, 110 betegnél ennél többször, 59 csecsemőnél háromszor, 41 betegnél négyszer és 10 gyermeknél ötször [43]. Hsu és mtsai szerint az újabb invaginatio esélye növekszik az újabb epizódok által [44]. Azaz harmadik kiújulás után a betegek $68 \%$-ában alakult ki negyedszer is invaginatio, a negyedik alkalom után pedig 100\%-ban alakult ki ötödik recidíva. Ezért $H s u$ a harmadik epizód után mütétet javasol.

A caecopexia kérdése: Recidiváló esetekben a caecum fixálása gyermekkorban nem elterjedt gyakorlat. Boehm és mtsai [45] egy esetben egy egyéves gyermeknél recidiváló invaginatio miatt végzett laparoszkópia során azt észlelték, hogy az ileocaecalis sphincter/billentyű nem záródik kellően, emiatt az invaginatiót nagyon könnyen provokálni tudták a mütét során. (Ez a lelet egyébként egybevág a korábban említett hipotézissel, miszerint az invaginatiót csecsemóknél az ileocaecalis sphincter kóros ellazulása okozhatja.) A szerzők a recidíva elkerülése végett az ileumot a caecumhoz varrták több öltéssel. A közlemény szerint a beteg tünetmentes volt a mütét után 10 hónappal. Mások ezt a megoldást nem javasolják; a rögzített ileum később panaszokat okozhat akár évek múlva is, de ez nincs konkrét esetekkel alátámasztva [46]. Li és mtsai (2018) retrospektív vizsgálatban elemezték a laparoszkópos ileocaecopexia szerepét a kettőnél többszöri csecsemókori recidíva esetén. 61 esetben végeztek mütétet (a hasfalhoz varrták mindkettőt), és átlag 19 hónap nyomon követés után mindössze 2 esetben $(3,2 \%)$ észleltek recidívát; bélelzáródásról nem számoltak be. A konzervatívan kezelt betegeknél szignifikánsan több recidívát észleltek: 25 betegnél (3 recidíva után) $18(72 \%)$ esetben, míg 16 betegnél (4 recidíva után) 14 esetben $(87,5 \%)$ alakult ki újabb recidíva [43]. Ezek alapján úgy tűnhet, hogy a kettőnél több recidíva esetén a laparoszkópos ileum- és caecumrögzítést érdemes megfontolni. Ugyanakkor nem szabad elfelejteni, hogy az ismételt konzervatív, ultrahang-ellenőrzés mellett végzett újabb desinvaginatio is jó noninvazív opció marad. A betegek majdnem fele az említett tanulmányban is a konzervatív kezelést választotta. A szerzők nem számoltak be olyan esetról, amikor a recidiváló invaginatio vezetett volna perforációhoz vagy egyéb komplikációhoz. Valószínú, hogy a 2. vagy 3. hidrosztatikus desinvaginatio nem okoz különösebb nehézséget, különösen, ha készülünk rá, bár erre vonatkozó tanulmányt nem találtunk. A jelen kézirat szerzőinek tapasztalatai szerint sem jellemző a sikeres desinvaginatio után kialakuló recidíva okozta komplikáció, mint a perforáció, peritonitis. Nagyon fontos, hogy a recidíva esetén gondoljunk a vezetőpontra, különösen idősebb gyermekekben. Ez az ultrahangon nem mindig mutatkozik. A bél áttapintásának nagy jelentősége van a vezetőpont felfedezésében. Erre a nyílt mütét több lehetőséget ad a laparoszkópiánál. A caecopexia ellen szólhat az is, hogy azzal egy életre szóló változást okozunk az anatómiában, annak összes potenciális következményével, egy csecsemőkori, akár „szezonálisnak” is tekinthető, konzervatívan többnyire jól kezelhető betegség prevenciójának céljából. Érdemes megfontolni azt is, hogy mütéti desinvaginatio után a recidíva nagyon alacsony, 1,7\% körül van caecopexia nélkül is [44]. Lehet a posztoperatív ileus, és a mütét utáni összetapadások is segíthetnek, esetleg az NSAID fájdalomcsillapítók is szerepet játszhatnak ebben.

Kórbonctani leletek alapján az ún. mobilis caecum a felnőtt populáció 25-65\%-ában fordul elő. Egyes szerzők mobilis caecum szerepét feltételezik az inkább felnőttkorban jellemző caecocolicus invaginatio kialakulásában, és ilyen esetben caecopexiát javasolnak [47]. Ugyanakkor Yamamato cikke szerint az 5 közölt esetből 4 esetben valamilyen vezetőpont (tumor) is szerepelt a leletek között, ami inkább a vezetőpont szerepére utalhat.

Mobilis caecum nem jellemző lelet a gyermekkori klasszikus ileocaecalis invaginatio esetén, a patogenezisben valószínúleg nem játszik szerepet. Mobilis caecum fixálása egyébként gyermekkorban nem javasolt, például malrotáció esetén sem.

\section{Desinvaginatio utáni ellátás}

A sikeres beavatkozás után a gyermeket mindenképpen meg kell figyelni. Egy tanulmányban 309 invaginatiós esetet vizsgáltak meg, és nem találtak szignifikáns különbséget a recidívára nézve azok között, akiket néhány órával a desinvaginatio után otthonukba bocsátottak, és azon gyermekek közt, akiket gyermeksebészeti osztályon figyeltek meg [48].

Jelenleg a magyar gyakorlatban legalább 24 órás kórházi tartózkodás az elfogadott, de nagy a szórás az esetek között (milyen hosszú az anamnesztikus idő, milyen nehezen lehetett elvégezni a desinvaginatiót).

A recidíva lehetőségét figyelembe véve a 48 óra eltelte utáni ismételt, akár ambuláns ultrahangvizsgálatnak lehet jelentősége. Ugyanakkor az olvasóban jogosan merülhet fel, hogy a rutinszerüen ismételt ultrahangvizsgálat az invaginatio „túldiagnosztizálásához” is vezethet, mely esetleges fölösleges kezelést indikálhat. Az ileocaecalis invaginatio spontán oldódásáról nem találtunk megbízható adatot. Spontán oldódása inkább az ileoilealis típusokra jellemző. Ezek az ultrahangon 2,5 cm-nél kisebb átmérővel bírnak, a betüremkedett bél hossza 3 cm-nél rövidebb, a bélfal perisztaltikája megtartott, és nincs vezetőpont [49].

A sikeres konzervatív kezelés után 2 órán belül megkezdett táplálás nem jár nagyobb kockázattal, sőt egyes vizsgálatok szerint a recidíva is kevesebb [50].

\section{Prognózis}

Korai diagnózis és az időben megtörtént kezelés esetén a prognózis jó, a halálozás 1\% alatti. Elmaradt diagnózis és kezelés esetén az invaginatio halálos kimenetelú lehet, 2-5 napon belül. 


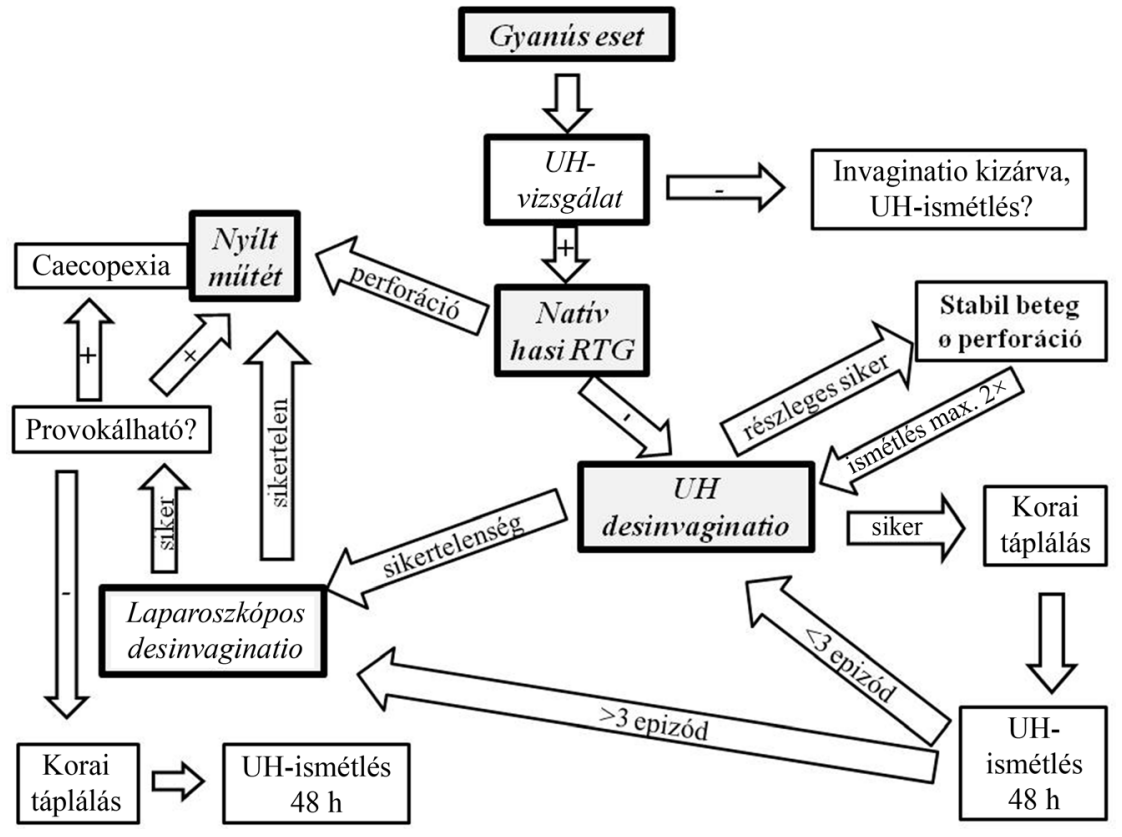

3. ábra

$\mid \begin{aligned} & \text { Javasolt ellátási protokoll } \\ & \mathrm{RTG}=\text { röntgen; } \mathrm{UH}=\text { ultrahang }\end{aligned}$

\section{Következtetés}

Az elmúlt évtizedben az invaginatióval kapcsolatos tudásunk gyarapodott. A szezonalitás igazolódott, a védőoltások biztonságosabbak lettek. Az LPS-állatmodellel szerzett tapasztalatok, az ileocaecalis átmenet neuroanatómiájának sajátosságai rávilágítottak, hogy az invaginatio hátterében a „vezetőpont-elmélet” mellett az ileocaecalis junctio motilitasi zavara is szerepet játszik. Ez a felismerés a jövőben újabb terápiás lehetőségek felismeréséhez is vezethet, például a konzervatív desinvaginatio hatékonyságának gyógyszeres fokozása vagy a recidíva kialakulásának csökkentése; jelenleg azonban bizonyítottan hatékony gyógyszeres kezelés még nem áll rendelkezésre.

A konzervatív desinvaginatio trendje az ultrahang-ellenőrzés mellett, folyadékkal végzett manőver felé fordult, melyet részleges redukció esetén célszerü ismételni akár kétszer is. Sikeres konzervatív kezelést követően a 2 órán belül elkezdett táplálás csökkenti a recidíva esélyét.

A sebészeti kezelés a minimálinvazív laparoszkópia felé fordult. Továbbra is vitatott az appendix eltávolításának szükségessége és kockázata, illetve a caecum és ileum fixálásának szükségessége többszörös recidíva esetén. $\mathrm{Ez}$ az irodalmi áttekintés és a jelenleg folyamatban lévő hazai multicentrikus vizsgálat további segítséget adhat egy egységes, frissített kezelési protokoll kialakításához (3. ábra).

Anyagi támogatás: A cikk megírása anyagi támogatásban nem részesült.
Szerzői munkamegosztás: B. D.: Az irodalom áttekintése, cikkek keresése, a kézirat megszövegezése. K. Á. L., R. Gy.: Szakmai vezetés, a kézirat javítása, véleményezése. A cikk végleges változatát valamennyi szerző elolvasta és jóváhagyta.

Érdekeltségek: A szerzőknek nincsenek érdekeltségeik.

\section{Irodalom}

[1] Pokorny WL, Wagner ML, Harberg FJ. Lateral wall cecal filling defects following successful hydrostatic reduction of cecalcolic intussusceptions. J Pediatr Surg. 1980; 15: 156-159.

[2] Dénes J. Intussusception. In: Dénes J. (ed.) Pediatric surgery and its frontiers. [Invaginatio. In: Dénes J. (szerk.) Gyermeksebészet és határterületei.] Medicina Könyvkiadó, Budapest, 1987; pp. 249-254. [Hungarian]

[3] Coran AG, Caldamone A, Adzick NS, et al. Intussusception. In: Coran AG, Caldamone A, Adzick NS, et al. (eds.) Pediatric surgery. 7th edn. Elsevier, Philadelphia, PA, 2012; pp. 1093-1110.

[4] Ratu FT, Reyburn R, Tuivaga E, et al. Epidemiology of intussusception before and after rotavirus vaccine introduction in Fiji. Sci Rep. 2018; 8: 11194.

[5] Ravitch MM. Intussusception. In: Welch KJ, Randolph JG, Ravitch MM, et al. Pediatric Surgery. 4th edn. Mosby Year Book, Chicago, IL, 1986; p. 868.

[6] Blanch AJ, Perel SB, Acworth JP. Paediatric intussusception: epidemiology and outcome. Emerg Med Australas. 2007; 19: 4550.

[7] Ein SH, Alton D, Palder SB, et al. Intussusception in the 1990s: Has 25 years made a difference? Pediatr Surg Int. 1997; 12: 374-376.

[8] DiFiore JW. Intussusception. Semin Pediatr Surg. 1999; 8: $214-$ 220.

[9] Ein SH, Stephens CA. Intussusception: 354 cases in 10 years. J Pediatr Surg. 1971; 6: 16-27. 
[10] Buettcher M, Baer G, Bonhoeffer J, et al. Three-year surveillance of intussusception in children in Switzerland. Pediatrics 2007; 120: 473-480.

[11] Winesett MP, Pietsch JB, Barnard JA. Yersinia enterocolitica in a child with intussusception. J Pediatr Gastroenterol Nutr. 1996; 23: 77-80.

[12] Contopoulos-Ioannidis DG, Halpern MS, Maldonado Y. Trends in hospitalizations for intussusception in California in relation ship to the introduction of new rotavirus vaccines, 1985-2010 Pediatr Infect Dis J. 2015; 34: 712-717.

[13] National Center for Epidemiology. Methodological letter about the vaccination of 2016. [Országos Epidemiológiai Központ. Módszertani levél a 2016. évi védőoltásokról.] Epinfo 2016; 23(Klsz 1). [Hungarian]

[14] Türkyilmaz Z, Karabulut R, Gülen S, et al. Role of nitric oxide and cyclooxygenase pathway in lipopolysaccharide-induced intussusception. Pediatr Surg Int. 2004; 20: 598-601

[15] Cserni T, Paran S, Puri P. New hypothesis on the pathogenesis of ileocaecal intussusception. J Paediatr Surg 2007; 42: 15151519

[16] Jin X, Wu F, Lei P. The role of hypergastrinemia in the pathogenesis of intussusception in infants. Zhonghua Wai Ke Za Zhi 1996; 34: 92-94.

[17] Kluwe WM, Page JG, Toft JD. Pharmacological and toxicological evaluation of orally administered pyridostigmine in dogs. Fundam Appl Toxicol. 1990; 14: 40-53.

[18] Kumar D, Phillips SF. The contribution of external ligamentous attachments to function of the ileocecal junction. Dis Colon Rectum 1987; 30: 410-416.

[19] Folaranmi S, Rakoczy G, Bruce J, et al. Ileocaecal valve - how important is it? Pediatr Surg Int. 2011; 27: 613-615.

[20] Soler WV, Lee AD, D'Albuquerque EM, et al. The effect of ileocecal valve removal in a model of short bowel syndrome. Arq Bras Cir Dig. 2019; 32: el417.

[21] Folaranmi SE. Clinical pathology of the ileocaecal junction in childhood and justification of its reconstruction as part of the autologus intestinal reconstructive surgery. $\mathrm{PhD}$ thesis. University of Debrecen, Doctoral School of Clinical Medicine, 2014. Available from: https://dea.lib.unideb.hu/dea/bitstream/ handle /2437/181723/Folaranmi_Semiu_ertekezes-t. pdf?sequence $=6 \&$ is Allowed $=y$ [accessed: March 2, 2020]

[22] Cserni T, Paran S, Kanyari Z, et al. New insight into the neuromuscular anatomy of the ileocecal valve. Anat Rec (Hoboken). 2009; 292: 254-261.

[23] Shafik A, El-Sibai O, Shafik AA. Physiological assessment of the function of the ileocecal junction with evidence of ileocecal junction reflexes. Med Sci Monit. 2002; 8: CR629-CR635.

[24] Cserni T. Intussusception. In: Cserni T, Rákóczy Gy. Everyday pediatric surgery. [Invaginatio. In: Cserni T, Rákóczy Gy. Mindennapi gyermeksebészet.] Melánia Kiadó, Budapest, 2012; pp. 197-200. [Hungarian]

[25] Xie X, Wu Y, Wang Q, et al. Risk factors for recurrence of intussusception in pediatric patients: A retrospective study. J Pediatr Surg. 2018; 53: 2307-2311.

[26] Fernández-Atutxa A, de Castro L, Arévalo-Senra JA, et al. Cannabis intake and intussusception: an accidental association? Rev Esp Enferm Dig. 2017; 109: 157-159.

[27] Kajimoto T, Dinning PG, Gibb DB, et al. Neurogenic pathways mediating ascending and descending reflexes at the porcine ileocolonic junction. Neurogastroenterol Motil. 2000; 12: 125134

[28] Fisher JK, Germann DR. Glucagon-aided reduction of intussusception. Radiology 1977; 122: 197-198.

[29] Franken EA Jr, Smith WL, Chernish SM, et al. The use of glucagon in hydrostatic reduction of intussusception: a double-blind study of 30 patients. Radiology 1983; 146: 687-689.

[30] Henry MC, Breuer CK, Tashjian DB, et al. The appendix sign: a radiographic marker for irreducible intussusception. J Pediatr Surg. 2006 ; 41: 487-489
[31] Gluckman S, Karpelowsky J, Webster AC, et al. Management for intussusception in children. Cochrane Database Syst Rev. 2017; 6: CD006476

[32] Xie X, Wu Y, Wang Q, et al. A randomized trial of pneumatic reduction versus hydrostatic reduction for intussusception in pediatric patients. J Pediatr Surg. 2018; 53: 1464-1468.

[33] Navarro OM, Daneman A, Chae A. Intussusception: The use of delayed, repeated reduction attempts and the management of intussusceptions due to pathologic lead points in pediatric patients. Am J Roentgenol. 2004; 182: 1169-1176.

[34] Pazo A, Hill J, Losek JD. Delayed repeat enema in the management of intussusception. Pediatr Emerg Care 2010; 26: 640645.

[35] Ferris M, Quan S, Kaplan BS, et al. The global incidence of appendicitis. Ann Surg. 2017; 266: 237-241.

[36] Wu SC, Chen WTL, Muo CH, et al. Association between appendectomy and subsequent colorectal cancer development: an Asian population study. PLoS ONE 2015; 10: e0118411.

[37] Fraser JD, Aguayo P, Ho B, et al. Laparoscopic management of intussusception in pediatric patients. J Laparoendosc Adv Surg Tech A 2009; 19: 563-565.

[38] Hill SJ, Koontz CS, Langness SM, et al. Laparoscopic versus open reduction of intussusception in children: experience over a decade. J Laparoendosc Adv Surg Tech A 2013; 23: 166-169.

[39] Daneman A, Navarro O. Intussusception. Part 2: An update on the evolution of management. Pediatr Radiol. 2004; 34: 97108.

[40] Ein SH, Mercer S, Humphry A, et al. Colon perforation during attempted barium enema reduction of intussusception. J Pediatr Surg. 1981; 16: 313-315.

[41] Maoate KM, Beasley SW. Perforation during gas reduction of intussusception. Pediatr Surg Int. 1998; 14: 168-170.

[42] Daneman A, Alton DJ, Lobo E, et al. Patterns of recurrence of intussusception in children: a 17 -year review. Pediatr Radiol. 1998; 28: 913-919.

[43] Li B, Sun CX, Chen WB, et al. Laparoscopic ileocolic pexy as preventive treatment alternative for ileocolic intussusception with multiple recurrences in children. Surg Laparose Endosc Percutan Tech. 2018; 28: 314-317.

[44] Hsu WL, Lee HC, Yeung CY, et al. Recurrent intussusception: when should surgical intervention be performed? Pediatr Neonatol. 2012; 53: 300-303.

[45] Boehm R, Till H. Recurrent intussusceptions in an infant that were terminated by laparoscopic ileocolonic pexie. Surg Endosc. 2003; 17: 831-832.

[46] Anand RJ, Shah SR, Kane TD. Laparoscopic management of delayed recurrent intussusception in an older child. JSLS 2007; 11 : 106-108.

[47] Yamamoto T, Tajima Y, Hyakudomi R, et al. Case of colonic intussusception secondary to mobile cecum syndrome repaired by laparoscopic cecopexy using a barbed wound suture device. World J Gastroenterol. 2017; 23: 6534-6539.

[48] Whitehouse JS, Gourlay DM, Winthrop AL, et al. Is it safe to discharge intussusception patients after successful hydrostatic reduction? J Pediatr Surg. 2010; 45: 1182-1186.

[49] Kim JH. US features of transient small bowel intussusception in pediatric patients. Korean J Radiol. 2004; 5: 178-184.

[50] Forati S, Yaghmaii B, Allah-Verdi B. The effect of early feeding after enema reduction of intussusception in order to investigate the rate of recurrence and side effects of reduction. Biomed Res. 2017; 28(13): 5642-5645. Available from: https://www. alliedacademies.org/articles/the-effect-of-early-feeding-afterenema-reduction-of-intussusception-in-order-to-investigatethe-rate-of-recurrence-and-side-effec-7793.html [accessed: March 2, 2020].

(Bodnár Dóra dr.,

Miskolc, Blaskovics u. 6. fszt. 3., 3526 e-mail: dorizig@gmail.com)

A cikk a Creative Commons Attribution 4.0 International License (https://creativecommons.org/licenses/by/4.0/) feltételei szerint publikált Open Access közlemény. (SID_1) 